The methodology will involve analysis of data from a random sample of employees based on income levels and places of employment. It is hoped that three cities in Nigeria and two in Ghana will be covered.

The supervisor of this study, Mrs. Rowena Lawson, Department of Agricultural Economics, University of Leeds, Leeds, 2, would be pleased to receive any suggestions about the study and to learn of similar research elsewhere.

\title{
International African Institute: Research Information Liaison Unit
}

THE International Register of Organisations undertaking Africanist Research in the Social Sciences and Humanities, compiled by Merran Fraenkel, is now available $\left(f_{3} \cdot 00\right)$. It gives details of the structure, personnel, and research disciplines of nearly 800 organizations (including university departments, research institutes and centres, and museums) in which Africanist research is undertaken. The information presented is drawn from replies to an inquiry circulated during the second half of 1970 , from communications and lists received from a number of national organizations, and from details in the International African Institute's own records. The publication is intended as a general work of reference for Africanists, and also as a framework for the assembly of information on current research projects.

The first of a series of International Bulletins on Current Africanist Research in the Social Sciences and Humanities is in preparation. The Bulletins will include:

(a) Brief listing of the aims, methods and scope of all relevant research projects under way in and on the several regions of Africa.

(b) Reports on research developments and needs in particular regions or subjects.

(c) News on the formation of new institutes and centres, on the initiation of large-scale research projects, on conferences and seminars recently held, and on changes in the structure or policies of existing organizations. This is an extension of the service provided up to the present in the 'Notes and News' section of the Institute's journal Africa.

(d) Requests from persons undertaking comparative research on specific topics for contacts with others working on similar topics.

Contributions under these headings are invited by the Research Information Liaison Unit. Under item (a)-the listing of research projects-arrangements for the exchange of information have been made with the Centre d'Analyse d'Afrique Noire, which collects and publishes information on research in France and the former French territories in Africa, and with the African Studies Association of the United Kingdom. Similar arrangements are being discussed with the African Studies Association of the U.S.A. For other countries, a questionnaire form is being circulated to research workers, either directly by the Unit or through local or national organizations. It would be appreciated if research workers who have not yet received an inquiry through one of these channels (or who have not yet replied to it) would send to the Research Information Liaison Unit brief information on their current research activities, under the headings listed on the sample form RILU/3 printed at the back of this number of Africa. 